\title{
Új low back pain prevenciós mozgásprogram, amely javítja a törzsizmok állapotát és a lumbalis motoros kontrollt
}

\author{
Kovácsné Bobály Viktória ${ }^{1,2}$. Szilágyi Brigitta ${ }^{1}$ - Makai Alexandra ${ }^{1,2}$ \\ Koller Ákos dr. ${ }^{3,4}$. Járomi Melinda dr. ${ }^{1}$ \\ ${ }^{1}$ Pécsi Tudományegyetem, Egészségtudományi Kar, Fizioterápiás és Sporttudományi Intézet, Pécs \\ ${ }^{2}$ Pécsi Tudományegyetem, Egészségtudományi Doktori Iskola, Pécs \\ ${ }^{3}$ Testnevelési Egyetem, Természettudományi Intézet, Sportgenetikai és Sportgerontológiai Kutatócsoport, Budapest \\ ${ }^{4}$ Pécsi Tudományegyetem, Általános Orvostudományi Kar, Idegsebészeti Klinika, Pécs
}

\begin{abstract}
Bevezetés: A balett-táncosok gyakran szenvednek deréktáji fájdalomtól. Célkitüzés: Speciális mozgásprogrammal, a törzsizmok erősítése révén, a deréktáji fájdalmak csökkentése. Módszer: 62 balett-táncosnőt (átlagéletkor: 14,89 $\pm 1,21$ év) vizsgáltunk. Kezelt csoport: $\mathrm{n}=30$ fó, átlagéletkor: 14,86 \pm 1,00 év, kontrollcsoport: n = 32 fó, átlagéletkor: $14,91 \pm 1,37$ év. Vizuális analóg skálával vizsgáltuk az edzéseken jelentkező derékfájdalom intenzitását, fotogrammetriás vizsgálattal habituális testtartásukat, Kraus-Weber-teszttel a hasizmok erejét, core-teszttel a törzsizmok statikus erejét, leg lowering teszttel a lumbalis motoros kontroll képességet. A kezelt csoport három hónapig LBP prevenciós mozgásprogramot végzett, majd újból elvégeztük a vizsgálatokat. Eredmények: Szignifikánsan csökkent az esetcsoport derékfájásának intenzitása (VAS1: $\mathrm{p}=0,012 ; \mathrm{VAS} 2: \mathrm{p}=0,021)$, szignifikánsan javult hasizomereje $(\mathrm{K}-\mathrm{W}$. $\mathrm{B}: \mathrm{p}=0,025 ; \mathrm{K}-\mathrm{W}$. C: $\mathrm{p}<0,001$ ), a törzsizmok statikus ereje (core-test: $\mathrm{p}<0,001$ ), lumbalis motoros kontroll képessége, mindkét láb esetében (Leg low. J.: p <0,001; Leg low. B.: $\mathrm{p}<0,001$ ). A habituális testtartás magas százalékban javult (elölnézet: $34,78 \%$, oldalnézet: $52,17 \%$ ). Következtetés: A speciális mozgásprogrammal csökkenthető a baletttáncosok derékfájdalma, a sérülések előfordulási gyakorisága. Orv. Hetil., 2017, 158(2), 58-66.
\end{abstract}

Kulcsszavak: balett, lumbalis motoros kontroll képesség, derékfájás, mozgásprogram

\section{Improvement of lumbal motor control and trunkmuscle conditions with a novel low back pain prevention exercise program}

\begin{abstract}
Introduction: Ballet dancers often suffer from low back pain. Aim: Low back pain can be reduced by strengthening the core muscles with the help of a special exercise program. Materials and methods: In the study 62 ballet dancer women (average age: $14.89 \pm 1.21$ years) were included. Intervention group: $\mathrm{n}=30$ participant, average age: 14.86 \pm 1.00 years, control group: $\mathrm{n}=32$ participant, average age: $14.91 \pm 1.37$ years. We examined the pain intensity that occurs during training with visual analog scale, the habitual posture with photogrammetry, the abdominal muscle strength with Kraus-Weber test, the static muscle strength of the trunk muscles with core test and the lumbar motor control with leg lowering test. The intervention group did a trunk prevented exercise program during 3 months, and then we examined them again. Results: In the intervention group the intensity of pain significantly decreased (VASI: $\mathrm{p}=0.012$; VAS2: $\mathrm{p}=0.021)$, the abdominal muscle strength significantly improved $(\mathrm{K}-\mathrm{W} . \mathrm{B}: \mathrm{p}=0.025 ; \mathrm{K}-\mathrm{W}$. $\mathrm{C}: \mathrm{p}<0.001)$, the static muscle strength of trunk muscles significantly increased (Core-test: $\mathrm{p}<0.001)$ and the lumbar motor control significantly improved in both legs (Leg low. R.: p<0.001; Leg low. L.: p<0.001). Also, the habitual posture greatly improved (frontal view: $34.78 \%$, side view: $52.17 \%$ ). Conclusion: In ballet dancers with a special exercise program, which improves the conditions of trunk muscles, the motor control of lumbar regions can be improved and the lower back pain and the incidence of injuries can be reduced.
\end{abstract}

Keywords: ballet, trunk prevention, low back pain, exercise program

K. Bobály, V., Szilágyi, B., Makai, A., Koller, Á., Járomi, M. [Improvement of lumbal motor control and trunkmuscle conditions with a novel low back pain prevention exercise program]. Orv., Hetil., 2017, 158(2), 58-66.

(Beérkezett: 2016. október 12.; elfogadva: 2016. november 11.) 


\section{Rövidítések}

VAS = vizuális analóg skálák

A balett-táncosok esetén a legtöbb mozgás a törzsből indul ki, ezért nem megfelelő törzsizomzat esetén gyakran ki vannak téve derékfájdalomnak. Vaganova szerint „a test gazdája a törzs”, a törzs gazdája pedig a hátgerinc [1]. Mivel majdnem minden mozgás a törzsbőll indul ki, igen fontos, hogy a törzstartó és -mozgató izmok megfelelően kidolgozottak legyenek. A törzs dinamikus stabilizátorként múködik, ami azt jelenti, hogy a végtagok mozgásai előtt a has és a hátizmok megfeszülnek, stabilizálják a gerincet. A törzs dinamikus stabilizáló hatásának következtében a végtagok relatív ereje nő, az egyensúly javul [2].

A kortárs modern tánc egyik fontos alaptechnikája a Graham-technika, amelynek lényege a talajon való bemelegítésen alapszik, ennek során a gerinc bemelegítésére fektetik a fö hangsúlyt, és mind fekvő, mind ülő helyzetben a végtagok tehermentes bemelegítése megtörténik [3]. A különböző táncmûvészeti mozgásmintázatok segíthetnek a helyes test- és törzstartás kialakításában és annak automatizálttá válásában is. Ilyen például a kortárs modern tánc egyik technikája, az úgynevezett Limóntechnika, e szerint amennyiben a táncos számára automatikussá válik a helyes testtartás, úgy a mozgások kivitelezése stabil, gyors és könnyed lesz [4].

Ha a törzsizmok ereje és kidolgozottsága nem megfelelő, akkor a táncosok flexibilitása és terhelhetősége csökken és deréktáji fájdalmak is jelentkeznek [5]. A nemzetközi irodalom leírja, hogy a táncosok gyakran szenvednek deréktáji fájdalomtól [6]. A magyarországi felmérések szerint az egyik leggyakoribb panaszok közé tartozik [7] az inkább felnőttkorban, de a professzionális táncosok körében már tánctanulmányaik folytatása során is jelentkező derékfájás. A derékfájást sokszor a rotációs mozgások, forgás, ugrásból való leérkezés, emelés váltja ki [8]. Ennek fő oka, hogy az egyes táncműfajok végzése során gyakori az extrém lumbalis extensio vagy a tartósan fenntartott fokozott lumbalis lordosis helyzet. Ezek során az érintett területeken olyan neuromuscularis változások jöhetnek létre, amelyek gyakori fájdalomérzetet okozhatnak [9]. Az esetek többségének hátterében a porckorongok degeneratív elváltozásai, az intervertebralis rés csökkenése és a kisízületekben jelentkező elmozdulások állnak.

Vizsgálatunk fontosságát alátámasztja az a tény, hogy a fent leírt panaszok és sérülések gyakran a táncpályafutás végét is jelenthetik, elsősorban a professzionális táncosok körében. A legújabb kutatások célja olyan preventív mozgásprogramok kidolgozása, amelyek a táncosok körében speciálisan e problémák megelőzését, kezelését tennék lehetővé [10]. A preventív gerinctréningek fontosabb részei az izomegyensúly, a helyes testtartás és a megfelelő lumbalis motoros kontroll képesség kialakítása [11-13], amely a modern fizioterápia és sportterápia egyik kiemelkedő feladata.

\section{Módszer}

Kontrollált, longitudinális, nem randomizált vizsgálatot végeztünk, kényelmi mintavétellel, amelyet a három hónapos mozgásterápia után ismét elvégeztünk a vizsgált táncosokon. Beválasztási kritériumként a 15-18 év közötti életkort és a minimum hároméves rendszeres táncmúlt egy adott társulatnál vagy iskolánál. A vizsgálatban csak táncosnők vettek részt. Kizárási kritériumként adtuk meg a kezelést igénylő gerincbetegséget, gerincmútétet, sportsérülést az elmúlt három hónapban, valamint low back pain (LBP) prevenciós mozgásprogramon való részvételt az elmúlt fél évben. A felmérés során 62 baletttáncosnőt vizsgáltunk ( $\mathrm{n}=62$, átlagéletkor: $14,89 \pm 1,21$ év). Az egész mintára jellemző, hogy a vizsgált táncosok fiatal életkoruk ellenére már átlagosan 5,22 $\pm 2,38$ éve táncolnak, heti átlagosan 3,02 \pm 1,02 edzésszámban, amelyek időtartama átlagosan $100 \pm 28,08$ perc. A rendszeres heti edzések mellett havi rendszerességgel átlagosan 1,49 $\pm 1,27$ színpadi előadáson vettek részt, ami $34,21 \pm 26,28$ percig tartott. A kezelt csoport (LBP prevenciós mozgásprogramot végző csoport) létszáma 30 fó, átlagéletkor: 14,86 \pm 1,00 (15-18) év. A balett-táncosok átlagosan 4,93 $\pm 2,01$ éve táncolnak, heti $3 \pm 1,06$ (alkalom) edzésszámmal, ahol az edzések időtartama átlagosan $96 \pm 12,2$ perc, valamint havonta átlagosan $1,3 \pm 1,68$ (alkalom), 35,1 $\pm 26,11$ perces színpadi előadásaik vannak. A kontrollcsoport 32 foóból áll, átlagéletkor: 14,91 $\pm 1,37$ év. Átlagosan 5,57 $\pm 2,64$ éve táncolnak, heti $3,5 \pm 0,98$ (alkalom), $90 \pm 0,00$ perces edzésszámmal, amelyekhez havi átlagosan 1,47 \pm 1,24 (alkalom), 24,03 $\pm 21,54$ perces színpadi előadások társulnak.

A vizsgálatot a Pécsi Múvészeti Gimnázium és Szakközépiskola Tánctagozatának balett-táncos növendékei körében végeztük 2016. április 1. és 2016. július 1. között. A vizsgálat kutatásetikai engedélyszáma: 6143, amelyet a Pécsi Tudományegyetem, Klinikai Központ, Regionális és Intézményi Kutatásetikai Bizottság adott ki.

A statisztikai elemzést SPSS 20.0 programmal végeztük, átlagértéket, tapasztalati szórást számoltunk és párosított t-próbát, normalitásvizsgálatot, varianciaanalízist, valamint Wilcoxon-próbát alkalmaztunk.

A próbák segítségével vizsgáltuk, hogy a három hónapos LBP prevenciós mozgásprogramot végző csoport esetében a törzs állapotát meghatározó paraméterekben történik-e szignifikáns javulás, valamint, hogy a kontrollcsoport és a kezelt csoport között van-e különbség. A szignifikancia értékét $\mathrm{p}<0,05$ értékben határoztuk meg.

\section{A derékfájdalom intenzitása}

A derékfájás intenzitásának vizsgálatát vizuális analóg skálák (VAS) segítségével végeztük [12]. A vizsgálati alanyoknak saját megítélésük szerint, 100-as felosztású skálákon 0-100\%-ig kellett jelölniük a derékfájás intenzitá- 
sának mértékét (VASl: a deréktáji fájdalom mennyire befolyásolja az edzés közben nyújtott teljesítményt, VAS2: a deréktáji fájdalom mértéke edzés után). A $0 \%$ azt jelenti, hogy a fájdalom nem befolyásoló tényező a kérdésben (VAS1, VAS2) szereplő esetben, a 100\% pedig azt, hogy teljes mértékben befolyásolja azt.

\section{Habituális testtartás}

A táncosok habituális testtartásának vizsgálata fotogrammetriás módszerrel történt [14]. A vizsgálati személyekről három fénykép készült, egy elölnézeti és két oldalnézeti kép. A fényképeket falra ragasztott szimmetriarácsos felület előtt készítettük 2 m távolságból, Nixon Coolpix L21 géppel (fókusztávolság $=6,72 \mathrm{~mm}$, vaku: Flash fired, érzékenység: ISO 200, normálexpozíciós program, F-szám: 3,1). A szimmetriarácsos felület magassága $2 \mathrm{~m}$, szélessége $1 \mathrm{~m}$, rácsméret: $6,5 \times 6,5 \mathrm{~cm}$. A vizsgálat során arra kértük a táncosokat, hogy álljanak úgy, ahogy általában szoktak.

A habituális testtartást meghatározó paramétereket pontozással értékeltük. Frontális síkban, ha a vállak, illetve a medence vonala párhuzamos, 2 pontot, ha nem szimmetrikus, 1 pontot adtunk. A frontális síkú súlyvonal metszi az orr, köldök vonalát és a két lábfej között középen érinti a talajt, akkor 2 pont, fiziológiás lefutású frontális súlyvonal esetén, ha nem metszi ezeket a ponto- kat a fiziológiás súlyvonal, 1 pont. A sagittalis síkban, ha a gerinc görbületei fiziológiás mértékúek voltak, azt 3 pontnak értékeltük, ha afiziológiás, 2 pontot kaptak. A sagittalis síkban a súlyvonalnak metszenie kellett a fül középpontját, a lumbalis I-es és V-ös csigolyatestet, végül a malleolus lateralis vonalában eléri a talajt, 2 pont. Ha nem metszette a fenti képletek valamelyikét, 1 pont.

\section{Törzsizmok ereje és nyújthatósága}

A hasizmok erejét és a térdflexorok nyújthatóságát Kraus-Weber-teszt segítségével mértük $[15,16]$ (1. táblázat).

A törzsizmok statikus erejének vizsgálata core-teszt segítségével történt, amely során a vizsgált személyeket helyes plank testhelyzet megtartására kértük, és a pontos feladat-végrehajtás időtartamát mértük (maximum 120 s-ig). A kapott értékeket pedig értékelőtáblázat segítségével értékeltük [17] (2. táblázat).

\section{Lumbalis motoros kontroll képesség}

A táncosok lumbalis motoros kontroll képességét leg lowering teszttel vizsgáltuk [18, 19]. A vizsgálatot Stabilizer Pressure BIO-Feedback (Chattanooga 92101DDJO) mûszer segítségével végeztük (3. táblázat).

1. táblázat |A Kraus-Weber-teszt gyakorlatainak leírása és értékelése

\begin{tabular}{|c|c|c|}
\hline \multirow[t]{5}{*}{ Gyakorlat } & Gyakorlat leírása & Értékelés \\
\hline & $\begin{array}{l}\text { K-W B) } \\
\text { Háton fekvésben a karok tarkóra } \\
\text { tartása mellett teljes felülés végzése, } \\
\text { miközben egy segítő a talajra szorítja } \\
\text { a két alsó végtagot }\end{array}$ & $\begin{array}{l}\text { Teljes felülés } 10 \text { pont, fél felülés } \\
5 \text { pont, feladat sikertelen végrehajtása } \\
0 \text { pont }\end{array}$ \\
\hline & $\begin{array}{l}\text { K-W C) } \\
\text { Háton fekvésben, talpra húzott } \\
\text { lábakkal, és tarkóra tartással teljes } \\
\text { felülés végzése }\end{array}$ & $\begin{array}{l}\text { Teljes felülés } 10 \text { pont, fél felülés } \\
5 \text { pont, feladat sikertelen végrehajtása } \\
0 \text { pont }\end{array}$ \\
\hline & $\begin{array}{l}\text { K-W F) } \\
\text { Alapállásból törzshajlítás előre, majd } \\
\text { helyzet megtartása }\end{array}$ & $\begin{array}{l}10 \text { pont, amennyiben eléri a talajt, ha } \\
\text { nem, lemérjük a talaj-ujjhegy } \\
\text { távolságot és } 2,5 \mathrm{~cm} \text {-enként levonunk } \\
\text { egy pontot }\end{array}$ \\
\hline & & \\
\hline
\end{tabular}

Forrás: Ángyán, L.: Sportélettani vizsgálatok. Motio Kiadó Bt., Pécs, 1995. 


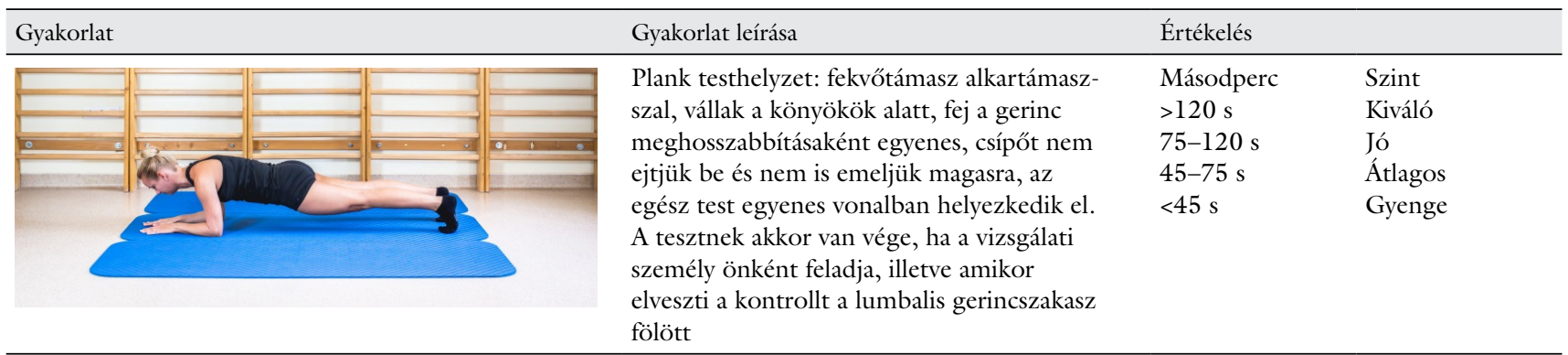

3. táblázat |A lumbalis motoros kontroll teszt leírása és értékelése

\begin{tabular}{|c|c|c|}
\hline Gyakorlat & Gyakorlat leírása & Értékelés \\
\hline & $\begin{array}{l}\text { A földön háton fekve helyezkedünk el, lábak } \\
\text { talpra húzva, karok test mellett. A műszer } \\
\text { párnás része derekunk alatt. A megfelelő test- } \\
\text { helyzet felvétele után felpumpáljuk a párnát } \\
40 \text { Hgmm-ig, majd arra kérjük a vizsgálati } \\
\text { személyeket, hogy hasizmuk segítségével, } \\
\text { derekukkal kezdjék el lefelé nyomni a párnát } \\
45 \text { Hgmm-ig, majd azt az utasítást adjuk, } \\
\text { hogy térdflexio mellett csípőflexiót hajtsanak } \\
\text { végre először a jobb, majd a bal térdükkel } \\
\text { úgy, hogy közben a műszer mutatóját igye- } \\
\text { kezzenek } 45 \text { Hgmm-nél tartani. A müszer } \\
\text { segítségével mindkét láb esetében rögzítjük a } \\
\text { mutató } 45 \mathrm{Hgmm-tól} \mathrm{történő} \mathrm{elmozdulásá-} \\
\text { nak minimum- és maximumértékét }\end{array}$ & $\begin{array}{l}\text { A } 45 \mathrm{Hgmm} \text {-tôl } 5 \mathrm{Hgmm} \text {-en belüli } \\
\text { eltérést tekintjük megfelelő lumbalis } \\
\text { motoros képességnek, az ennél na- } \\
\text { gyobb eltérés nem megfelelő lumba- } \\
\text { lis motoros képességet jelent }\end{array}$ \\
\hline
\end{tabular}

4. táblázat $\mid \mathrm{LBP}$ prevenciós mozgásprogram

\begin{tabular}{|c|c|c|c|c|c|c|}
\hline & $\begin{array}{l}\text { Testtartás-tudatosítás és } \\
\text {-automatizálás }\end{array}$ & $\begin{array}{l}\text { Ismétlésszám, } \\
\text { intenzitás }\end{array}$ & Izombalansz-gyakorlatok & $\begin{array}{l}\text { Ismétlésszám, } \\
\text { intenzitás }\end{array}$ & $\begin{array}{l}\text { Lumbalis motoros } \\
\text { kontroll gyakorlatok }\end{array}$ & $\begin{array}{l}\text { Ismétlésszám, } \\
\text { intenzitás }\end{array}$ \\
\hline 1. hónap & $\begin{array}{l}\text { Izometriás gyakorlatok } \\
\text { álló helyzetben, } \\
\text { elongáció }\end{array}$ & $\begin{array}{l}10 \times 10 \mathrm{~s} \\
50 \%\end{array}$ & $\begin{array}{l}\text { Felületes hátizmok } \\
\text { izotóniás koncentrikus } \\
\text { gyakorlatai hason fekvő } \\
\text { helyzetben, alulról } \\
\text { indított hasizom- } \\
\text { gyakorlatok }\end{array}$ & $\begin{array}{l}10-16 \text {-szor } \\
60 \%\end{array}$ & $\begin{array}{l}\text { Törzs- és vállövgyakor- } \\
\text { latok térdelő támasz } \\
\text { helyzetben }\end{array}$ & $10 \times 10 \mathrm{~s}$ \\
\hline 2. hónap & $\begin{array}{l}\text { Izometriás gyakorlatok } \\
\text { álló helyzetben, } \\
\text { elongáció }\end{array}$ & $\begin{array}{l}10 \times 10 \mathrm{~s} \\
50 \%\end{array}$ & $\begin{array}{l}\text { Felületes hátizmok } \\
\text { koncentrikus gyakorlatai } \\
\text { ülö és álló helyzetben, } \\
\text { alulról indított } \\
\text { hasizomgyakorlatok }\end{array}$ & $\begin{array}{l}16-18 \text {-szor } \\
70 \%\end{array}$ & $\begin{array}{l}\text { Törzs- és vállöv-stabili- } \\
\text { záló gyakorlatok külön- } \\
\text { böző testhelyzetekben }\end{array}$ & $10 \times 10 \mathrm{~s}$ \\
\hline 3. hónap & $\begin{array}{l}\text { Parallel, első és második } \\
\text { pozíción keresztül, álló } \\
\text { helyzetben felületes } \\
\text { hátizmok és oldalsó } \\
\text { hátizmok koncentrikus } \\
\text { gyakorlata }\end{array}$ & $\begin{array}{l}10-14 \times 10 \mathrm{~s} \\
\text { Kar-, } \\
\text { pozíció- } \\
\text { váltásokkal. }\end{array}$ & $\begin{array}{l}\text { Álló helyzetben parallel, } \\
\text { első és második } \\
\text { pozícióban, felületes } \\
\text { hát- és hasizmok } \\
\text { izometriás gyakorlatai, } \\
\text { demi és grand pliék } \\
\text { kombinálásával } \\
\text { combfeszítő izmok } \\
\text { izometriás gyakorlatai }\end{array}$ & 10-14-szer & $\begin{array}{l}\text { Parallel, első és } \\
\text { második pozícióban, } \\
\text { tendu, rond de jambe } \\
\text { par terre, rond de } \\
\text { jambe en l'air, és passé } \\
\text { szabadláb-mozgások, } \\
\text { dinamikus kartartások- } \\
\text { kal történő kombinálá- } \\
\text { sával, törzs- és } \\
\text { vállöv-stabilizáló } \\
\text { gyakorlatok, súlyláb } \\
\text { combfeszítő izmainak } \\
\text { izometriás gyakorlatai- } \\
\text { val }\end{array}$ & $\begin{array}{l}\text { Szabadláb mozgások } \\
\text { (csúsztatás, kiemelés) } \\
\text { dinamikus kartartás- } \\
\text { sal, mindkét lábra. } \\
\text { Gyakorlatok ideje: } \\
4-8 \mathrm{~s}\end{array}$ \\
\hline
\end{tabular}




\section{LBP prevenciós mozgásprogram}

Három hónapos, törzsizmokat erôsítő programot dolgoztunk ki, amelynek elsődleges célja a táncosok deréktáji fájdalmának primer, szekunder prevenciója, valamint a gerinccel kapcsolatos sportártalmak csökkentése, illetve a degeneratív gerincbetegségek megelőzése. A programot a nemzetközi előírásoknak megfelelően és a táncosok speciális igényei alapján alakítottuk ki: testtartásbeállitás, motoros kontroll gyakorlatok, stabilizációs terápia, progresszív erőtréning, táncspecifikus mozgásprogram [20-22]. A program három egységbő́l áll:

$\mathrm{Az}$ elsố-második hónapban a helyes testtartáshoz szükséges izombalansz kialakítása és a testtartás tudatosítása, automatizálása volt a cél. A vizsgálatban részt vevők izomerősítő (musculus transversus abdominis, musculus multifidus, musculus erector spinae, musculus longissimus, mm rhomboidei) és nyújtó (pectoralis izomcsoport, térd-csípő flexor izomcsoport) gyakorlatokat, valamint lumbalis motoros kontroll képességet fejlesztő mozgásokat végeztek. A harmadik hónap mozgásanyaga izombalanszt és lumbalis motoros kontroll képességet fejlesztő gyakorlatokat tartalmazott táncspecifikus elemekkel [23] (4. táblázat).

\section{Eredmények}

\section{Az edzés közben nyújtott teljesitmény deréktáji fájdalom általi befolyásoltsága (VASI)}

Az eredmények azt mutatták, hogy kezdetben a kezelt csoport 7,66\%-a, a kontrollcsoportnak pedig $11,33 \%$-a ítélte meg úgy, hogy a derékfájás intenzitása negatívan befolyásolja edzés közben nyújtott teljesítményét. Az LBP prevenciós mozgásprogram elvégzése után az esetcsoport eredményei szignifikáns javulást mutattak $(\mathrm{p}=$ 0,012 ), a táncosoknak mindössze $1 \%$-a jelezte, hogy a fájdalom intenzitása negatívan befolyásolja edzés közben nyújtott teljesítményüket. A kontrollcsoport esetében a 12. hét elteltével még mindig a táncosok 10,33\%-a mondta, hogy a deréktáji fájdalom negatívan befolyásolja edzés közben nyújtott teljesítményüket, amely eredmény nem jelentett szignifikáns javulást $(\mathrm{p}=0,365)$.

\section{Az edzés után jelentkezö deréktáji fájdalom intenzitása (VAS2)}

Az edzés után jelentkező derékfájás intenzitása az elsô héten a kezelt csoportban 10,16\%-os volt, a kontrollcsoportban $9 \%$. A három hónapos mozgásprogram elvégzése után szignifikánsan javult $(\mathrm{p}=0,021)$ az esetcsoport edzés után jelentkező derékfájdalom-intenzitása, amelynek mértéke már csak 1,66\% volt a skálán jelzett intenzitási értékek alapján. A kontrollcsoport eredményei azonban azt mutatták, hogy a 12 . hét eltelte után a táncosok deréktáji fájdalmának intenzitása az edzések után még mindig 9,16\%-os, amely nem jelent szignifikáns $(\mathrm{p}=$ $0,804)$ javulást (5. táblázat).

\section{Habituális testtartás vizsgálata}

Az első héten a fotogrammetriás vizsgálat során a habituális testtartás elölnézeti képében az esetcsoport 33,3\%ánál, a kontrollcsoportnak 31,3\%-ánál tapasztaltunk nem fiziológiás testtartást. Az oldalnézet tekintetében a kezelt csoport 33,3\%-ának volt fokozott, 23,3\%-ának pedig elsimult a lumbalis lordosisa. A kontrollcsoport tekintetében a habituális oldalnézeti képnél a csoport 28,1\%ánál tapasztaltunk fokozott, 15,6\%-ánál pedig elsimult görbületet. Az LBP prevenciós mozgásprogram elvégzése (12. hét) után az elölnézet tekintetében 34,78\%nál, oldalnézet tekintetében pedig 52,17\%-nál tapasztaltunk javulást a kezelt csoport habituális testtartásában. A kontrollcsoport esetében az elölnézet tekintetében a csoport 30,8\%-ánál tapasztaltunk nem szimmetrikus testtartást, oldalnézet esetén a csoport 29,5\%-ánál tapasztaltunk fokozott, 14,4\%-ánál pedig elsimult görbületet.

\section{Törzsizmok ereje és nyújthatósága}

A hasizmok erejére a Kraus-Weber-teszt B) gyakorlata alapján a kezelt csoport mozgásterápia elótti pontszáma $9,16 \pm 1,89$, a kontrollcsoporté $9,17 \pm 1,99$ volt. A 12 . hetet követően szignifikánsan javult $(\mathrm{p}=0,025)$ a kezelt csoport hasizomereje, a gyakorlatra kapott pontszámok átlagértékeiben ez $10 \pm 0,00$ pontot jelentett. A kontrollcsoport esetében szignifikáns javulást nem tapasztaltunk ( $\mathrm{p}=0,738)$, a csoport átlagpontszáma ennél a gyakorlatnál 9,33 $\pm 1,72$ volt. A hasizmok erejét mérő Kraus-Weber-teszt C) gyakorlat tekintetében a kezelt csoport átlagpontszáma az első héten $7 \pm 2,49$, a kontrollcsoporté $7,50 \pm 2,54$ volt. A 12 . hét után szignifikánsan javult $(\mathrm{p}<0,001)$ a kezelt csoport hasizomereje, amelynek átlagpontszáma a maximális $10 \pm 0,00$ pontra javult. A kontrollcsoport esetében ennél a gyakorlatnál sem tapasztaltunk szignifikáns javulást $(\mathrm{p}=0,102)$, a 12 . hét elteltével a csoport átlagpontszáma $8,16 \pm 2,45$ volt. A nyújthatósági gyakorlat (Kraus-Weber-teszt F) tekintetében a kezelt csoport mozgásprogram előtti pontszáma $9,7 \pm 1,47$, a kontrollcsoporté $8,73 \pm 2,95$ volt. A 12. hét után szignifikáns javulást ugyan nem $(\mathrm{p}=0,317)$ kaptunk a kezelt csoport nyújthatóságát tekintve, de pontszámok tekintetében a maximális $10 \pm 0,00$ pontszámot érték el. A kontrollcsoport 12 hét utáni átlagpontszáma $9,21 \pm 2,29$ volt, amely ezen vizsgálati paraméter tekintetében sem jelentett szignifikáns $(\mathrm{p}=0,067)$ változást (6. táblázat). 
5. táblázat |Az edzések során jelentkező derékfájás intenzitása (\%)

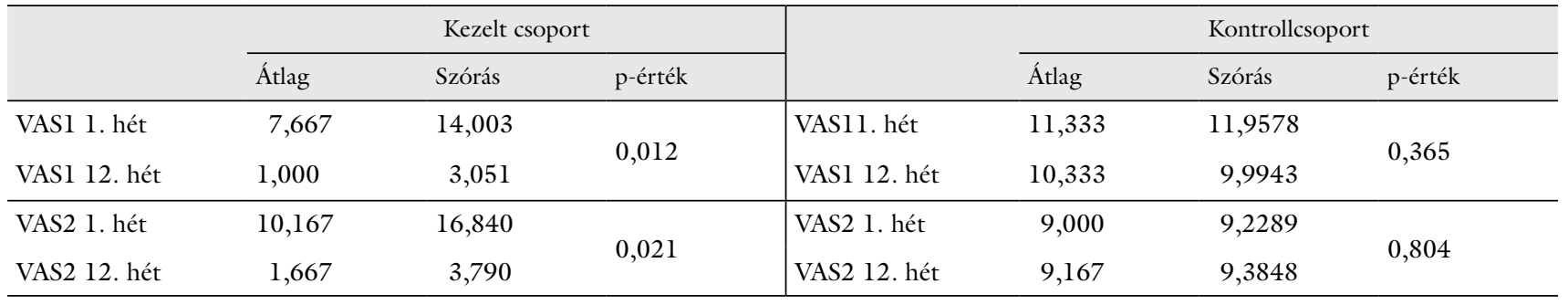

VAS1: Az edzés közben nyújtott teljesítmény deréktáji fájdalom általi befolyásoltsága.

VAS2: Az edzés után jelentkező deréktáji fájdalom intenzitása.

1. hét: alapfelmérés.

12. hét: 12. hét utáni felmérés.

6. táblázat | Kraus-Weber-teszt eredményei (pontszám)

\begin{tabular}{|c|c|c|c|c|c|c|c|}
\hline & \multicolumn{3}{|c|}{ Kezelt csoport } & & \multicolumn{3}{|c|}{ Kontrollcsoport } \\
\hline & Átlag & Szórás & p-érték & & Átlag & Szórás & p-érték \\
\hline K-W B) 1. hét & 9,167 & 1,895 & \multirow{2}{*}{0,025} & $\mathrm{~K}-\mathrm{W}$ B) 1. hét & 9,177 & 1,995 & \multirow{2}{*}{0,738} \\
\hline K-W B) 12. hét & 10,00 & 0,000 & & K-W B) 12. hét & 9,333 & 1,728 & \\
\hline K-W C) 1. hét & 7,000 & 2,491 & \multirow{2}{*}{0,001} & K-W C) 1. hét & 7,500 & 2,542 & \multirow{2}{*}{0,102} \\
\hline $\mathrm{K}-\mathrm{W}$ C) 12 . hét & 9,833 & 0,912 & & $\mathrm{~K}-\mathrm{W}$ C) 12 . hét & 8,167 & 2,450 & \\
\hline K-W F) 1. hét & 9,700 & 1,643 & \multirow{2}{*}{0,317} & K-W F) 1. hét & 8,987 & 2,806 & \multirow{2}{*}{0,067} \\
\hline K-W F) 12. hét & 10,00 & 0,000 & & $\mathrm{~K}-\mathrm{W}$ F) 12. hét & 9,210 & 2,292 & \\
\hline
\end{tabular}

K-W: Kraus-Weber-teszt.

1. hét: alapfelmérés.

12. hét: 12. hét utáni felmérés.

7. táblázat | Core-teszt eredményei (s)

\begin{tabular}{|c|c|c|c|c|c|c|c|}
\hline & \multicolumn{3}{|c|}{ Kezelt csoport } & & \multicolumn{3}{|c|}{ Kontrollcsoport } \\
\hline & Átlag (s) & Szórás & p-érték & & Átlag (s) & Szórás & p-érték \\
\hline Core 1. hét & 54,600 & 29,974 & \multirow{2}{*}{0,001} & Core 1. hét & 65,400 & 23,330 & \multirow{2}{*}{0,117} \\
\hline Core 12 . hét & 93,000 & 21,682 & & Core 12 . hét & 67,367 & 17,093 & \\
\hline
\end{tabular}

1. hét: alapfelmérés.

12. hét: 12. hét utáni felmérés.

\section{Core-teszt}

A törzsizomerő-vizsgálat során az első héten a kezelt csoport átlagosan 54,6 s-ig, a kontrollcsoport 65,4 s-ig tudta megtartani a plank testhelyzetet. Az értékelőtáblázat alapján az eredmények tükrében mindkét vizsgálati csoport az „átlagos” kategóriába tartozott. Az LBP prevenciós mozgásprogramot követően szignifikánsan javult $(\mathrm{p}<0,001)$ a kezelt csoport törzsizmainak statikus ereje, mert a három hónapos intervenciót követően a táncosok átlagosan 93 s-ig tudták tartani a plank testhelyzetet, amely már az értékelőtáblázat alapján a „jó” kategóriába tartozott. A kontrollcsoport esetében az eredmények hasonlóan alakultak a 12 hét eltelte után is, átlagosan 67,3 s-ig tudták megtartani a plank testhelyzetet, amely nem jelentett szignifikáns javulást $(\mathrm{p}=0,117)$ (7. táblázat).

\section{Lumbalis motoros kontroll képesség}

A leg lowering teszt első héten mért eredményei alapján a jobb láb esetében a kezelt csoportnál átlagosan 5,36 $\mathrm{Hgmm}$, a kontrollcsoportnál 5,05 Hgmm volt az átlagos eltérés, amely meghaladta a megengedett 5,00 Hgmmes eltérést. A bal lábat illetően a kezelt csoportnál 4,75 Hgmm-es, a kontrollcsoportnál 5,22 Hgmm-es eltérést tapasztaltunk, amely eredmények szerint csupán a kontrollcsoport eredményei haladták meg a megengedett el- 
térési értéket. A mozgásprogram hatására a kezelt csoport lumbalis motoros kontroll képessége a 12 . hét után szignifikánsan javult $(\mathrm{p}<0,001)$, ami a jobb láb esetén 3,78 Hgmm-t, a bal láb esetén 4,26 Hgmm-t jelentett. A kontrollcsoport esetében szignifikáns javulást sem a jobb ( $\mathrm{p}=0,094)$, sem a bal láb $(\mathrm{p}=0,295)$ esetében nem tapasztaltunk a 12 hét után. A vizsgálat során a jobb láb esetében még mindig 5,03 Hgmm, a bal láb esetében pedig 5,32 Hgmm volt az eltérés, amely nem megfeleló lumbalis motoros kontroll képességet jelent (8. táblázat).

\section{Megbeszélés}

\section{Derékfájdalom intenzitása és változása}

A vizuális analóg skálák segítségével a vizsgálat során megállapítottuk, hogy a táncosok körében a derékfájás már viszonylag fiatal életkorban jelentkezik, ami meghatározza az edzéseken nyújtott teljesítményüket és ami jelentkezik az edzések után is. A fájdalom intenzitása az LBP prevenciós mozgásprogramot követően szignifikánsan csökkent.

Hagins és mtsai Oswestry Disability Index segítségével végeztek kérdőíves felmérést a derékfájás tekintetében. A 37 professzionális táncosnő vizsgálata során ötéves visszatekintésben elemezték azon panaszok és sérülések előfordulását, amelyek a gerincfunkció vesztéséhez és a ThXII-LI gerincszegment degeneratív elváltozásaihoz vezettek. A táncosok mindegyike arról számolt be, hogy öt hónap eltelte után a sérült mozgásszegment teljes funkciója visszaállt és a fájdalom jelentősen csökkent. A vizsgálat során a táncosok gerincstabilizációs mozgásprogramot végeztek, amelynek eredményeként a kezdetben mért $48 \%$-os sérülési valószínúség $26 \%$-ra csökkent [24].

\section{Habituális testtartás}

A fotogrammetriás vizsgálat során mindkét vizsgálati csoportnál azt tapasztaltuk, hogy jelentős százalékban fordult elő a fokozott lumbalis lordosis, amely a kezelt csoport esetében magas százalékban javult az alkalmazott mozgásprogram hatására.

Iunes és mtsai 52 fó, 24 éves korú balett-táncosnő körében végzett fotogrammetriás módszerrel hasonló vizsgálatot a lumbalis lordosis tekintetében. A táncosokat 59, hasonló korú nem táncos kontrollcsoporttal hasonlították össze. A méréseket három éven keresztül végezték, amelynek célja a lumbalis lordosis változásának vizsgálata volt. Az eredményeik azt mutatták, hogy a balett-táncosok esetében szignifikánsan nőtt a fokozott lumbalis lordosis előfordulása [25].

\section{Törzsizmok ereje és nyújthatósága}

A Kraus-Weber-teszttel végzett eredményeink azt mutatták, hogy a balett-táncosok hasizomereje a pontszámok alapján átlagosnak tekinthető. Az LBP prevenciós mozgásprogram segítségével a kezelt csoport hasizomereje szignifikánsan javult, míg a kontrollcsoport esetében javulás nem volt megfigyelhető. Az izomnyújthatóság tekintetében hasonló eredményt kaptunk, a táncosok megfelelő nyújthatósági paraméterekkel rendelkeztek már a mozgásprogram elvégzése előtt. A mozgásprogram hatására a kezelt csoport esetében azonban e paraméterben is javulást tapasztaltunk, bár a javulás mértéke nem bizonyult szignifikánsnak. Ennek oka az, hogy a klasszikus balett-tréning számos olyan gyakorlatot tartalmaz, amely kifejezetten az izomnyújthatóság fokozására irányul, a testtartás szempontjából jelentős izmokra (csípőflexor izomcsoport, pectoralis izomcsoport) azonban nem, holott ezen izmok nyújthatósága a helyes testtartás kialakítása mellett a megfelelő izombalansz kialakításában is jelentős szerepet játszik [26].

A core-teszt alapján megállapítottuk, hogy a törzsizmok statikus ereje a rendszeres edzések ellenére sem megfelelő, de LBP prevenciós mozgásprogram rendszeres alkalmazásával jelentős mértékben javítható (7. táblázat). Felmérésünkben a kezelt csoport esetében a mozgásprogramot követően szignifikánsan nőtt a törzsizmok statikus ereje.

Swain felmérésében táncosok törzsizom-állóképességét vizsgálták oldalra fordult plank teszt segítségével.

8. táblázat |A leg lowering teszt eredményei (Hgmm)

\begin{tabular}{|c|c|c|c|c|c|}
\hline & \multicolumn{2}{|c|}{ Kezelt csoport } & & \multicolumn{2}{|c|}{ Kontrollcsoport } \\
\hline & $\begin{array}{c}\text { Különbségek } \\
\text { (Hgmm) }\end{array}$ & p-érték & & $\begin{array}{c}\text { Különbségek } \\
(\mathrm{Hgmm})\end{array}$ & p-érték \\
\hline Leg low. jobb 1 . hét & 5,36 & \multirow{2}{*}{0,001} & Leg low. jobb 1. hét & 5,05 & \multirow{2}{*}{0,094} \\
\hline Leg low. jobb 12 . hét & 3,78 & & Leg low. jobb 12. hét & 5,03 & \\
\hline Leg low. bal 1. hét & 4,75 & \multirow{2}{*}{0,001} & Leg low. bal 1. hét & 5,22 & \multirow{2}{*}{0,295} \\
\hline Leg low. bal 12 . hét & 4,26 & & Leg low. bal 12 . hét & 5,32 & \\
\hline
\end{tabular}

Leg low.: Leg lowering teszt.

1. hét: alapfelmérés.

12. hét: 12. hét utáni felmérés. 
A kapott eredmények ezeknél a vizsgálatoknál is azt mutatták, hogy a táncosok törzsizom-állóképessége nem megfelelő. Gyakran találkozunk a jobb és a bal oldal között szignifikáns különbségekkel, amely fiziológiás [27].

\section{Lumbalis motoros kontroll képesség}

A leg lowering teszt során kapott eredményeink alapján azt mondhatjuk, hogy a balett-táncosok lumbalis motoros kontroll képessége nem megfelelő, amely azonban célzott mozgásprogram rendszeres végzésével nagymértékben javítható, hiszen a kezelt csoport esetében e paraméter tekintetében is szignifikáns javulást értünk el mindkét láb esetében (8. táblázat).

Roussel és mtsai végeztek hasonló vizsgálatot táncosok körében azzal a céllal, hogy összehasonlítsák a lumbalis motoros kontroll képességet, az izomnyújthatóságot derékfájós és nem derékfájós táncosok között. A vizsgálatot 40 fớ, a professzionális pályafutás előtt álló táncosnők (átlagéletkor: 20,3 év) körében végezték. A táncosokat klinikai tesztekkel vizsgálták, amely lumbalis motoros kontroll tesztből, izomnyújthatóság-tesztből, általános ízületi mozgékonyságot vizsgáló tesztből és a sacroiliacalis fájdalmat provokáló speciális tesztekből állt. Az eredmények azt mutatták, hogy azoknak a táncosoknak, akiknek kórtörténetében szerepelt derékfájás, szignifikánsan gyengébb a lumbalis motoros kontrollja, mint azoknak, akik nem szenvedtek derékfájástól. Az izomnyújthatóság és a hipermobilitás tekintetében nem tapasztaltak összefüggést a táncosok között. A vizsgálat során megállapították, hogy fiatal korukhoz képest igen gyakori a derékfájás előfordulása, amelynek oka a csökkent lumbalis motoros kontroll képesség, ezért fejlesztésére nagy hangsúlyt kellene fektetni a táncosok körében [28].

Mistiaen és mtsai professzionális balett-táncosok körében végeztek vizsgálatot, amelynek az volt a célja, hogy bebizonyítsák, a motoros kontroll gyakorlatok segítségével csökkenthető a sérülések előfordulási valószínüsége. A vizsgálatban 40 főiskolás balett-táncos vett részt, akik a táncórák mellett speciális motoros kontroll tréninget végeztek hat hónapon keresztül. A sérülések előfordulási arányán kívül, a szubmaximális erő-állóképességi teszttel vizsgálták a táncosok állóképességét is. Az eredményeik azt mutatták, hogy szignifikánsan csökkent $(\mathrm{p}<0,05)$ a sérülések előfordulási gyakorisága és nőtt a táncosok állóképessége $(\mathrm{p}<0,001)$ is. Így a szerzők arra a következtetésre jutottak, hogy a motoros kontroll tréningnek fontos szerepe van a sérülések előfordulási valószínúségének csökkentésében és növeli az erő-állóképességet is [29].

A sportolók körében már elterjedt az LBP prevenciós mozgásprogramok alkalmazása, mint például a core-tréning, gerinciskola, gerincstabilizációs tréning, motoros kontroll gyakorlatok vagy a neuromuscularis tréning [30, 31]. Ezeknek a prevenciós programoknak a hatására csökken a derékfájdalom intenzitása, a derékfájós epizódok száma azáltal, hogy az egyoldalú edzés vagy rossz testtartás hatására kialakult izomdiszbalansz csökken. Az LBP prevenciós programok általános és sportágspecifikus részből állnak. Az általános rész statikus törzsizomerő-fejlesztő gyakorlatokat tartalmaz. A sportágspecifikus rész a sport, illetve a tánc sajátos mozgásformáin keresztül gyakoroltatja a statikus és dinamikus törzsizomgyakorlatokat, valamint fejleszti a helyes testtartáshoz lényeges és a derékfájdalom prevenciója szempontjából fontos lumbalis motoros kontroll képességet, automatizálja a helyes testtartást [32-34].

Rickman és mtsai kutatásukban szintén arról számoltak be, hogy a táncosok körében igen nagy gyakorisággal fordulnak elő a gerincet érintő panaszok, sérülések, különösen nagy százalékban a deréktáji régiót tekintve. Így a testtartásban szerepet játszó izmok megerősítésére szolgáló gyakorlatokból álló törzsstabilizációs program alkalmazását javasolták a hivatásos táncosok körében [35].

\section{Következtetés}

A vizsgálatunkban részt vevő táncosok körében nagy százalékban fordult elő az afiziológiás testtartás. A legnagyobb százalékban a fokozott lumbalis lordosis volt jellemző, amelynek hátterében a helyes testtartás kialakításában részt vevő törzsizmok gyengesége és a nem megfelelő lumbalis motoros kontroll képesség állhat. Továbbá a táncosok habituális testtartása nem egyezik meg a biomechanikailag helyes testtartással. Feltehetően ezen elváltozások felelősek a deréktáji fájdalmaik kialakulásában. A vizsgálatainkban alkalmazott specifikus törzsizom-erősítő mozgás prevenciós program jelentősen javította a táncosok testtartását és csökkentette a deréktáji fájdalmat is, feltehetően csökkentette a gerincsérülés bekövetkezésének rizikóját. Mindezek miatt fontos, hogy a táncosok már fiatal korban - párhuzamosan az edzéssel és versenyszerü fellépéssel - folyamatos speciális mozgásterápiában részesüljenek.

Mindezek mellett a mozgásprogram a derékfájdalom primer prevencióját célozhatja sportolók körében is. A teljes mozgásprogram azoknál a sportoknál használható, ahol a balett a mozgásanyagban vagy kiegészítő edzésprogramban szerepel úgy, mint az egyes táncstílusok (kortárs modern tánc, társastánc, néptánc, ír sztepptánc) és esztétikai sportágak (ritmikus gimnasztika, torna, aerobic, szinkronúszás, jégtánc, múkorcsolya) esetében. A mozgásprogram első része gyermekeknek is 10 éves kortól javasolható primer prevenciós céllal. A program első két része alkalmazható (törzsizomfejlesztés, izomegyensúly-kialakítás, lumbalis motoros kontroll fejlesztése, helyes testtartás kialakítása) minden sportág sportolói, hobbisportolói, de még a nem sportolók körében is primer prevenciós céllal. Gyógytornász vezetése mellett pedig javasolható LBP betegeknek szekunder prevenciós céllal [35]. A mozgásprogram harmadik része (táncspecifikus mozgásanyag) rekreációs mozgásanyagként vagy sportterápiaként is használható. 
Anyagi támogatás: A szerzők anyagi támogatásban nem részesültek.

Szerzői munkamegosztás: J. M., K. B. V.: A vizsgálat tervezése és lefolytatása. M. A.: Statisztikai elemzések. J. M., K. B. V.: Irodalomkutatás. K. Á., Sz. B., J. M., K. B. V.: A kézirat megszövegezése. A cikk végleges változatát valamennyi szerző elolvasta és jóváhagyta.

Érdekeltségek: A szerzóknek nincsenek érdekeltségeik.

\section{Irodalom}

[1] Biewald, F.: Das Bobath-Konzept. Urban und Fischer, München, 2004, 20-23.

[2] Lórinc, K.: After Martha Graham. [Martha Graham nyomában.] Planétás Kiadó Kft., Budapest, 2007, 5-10. [Hungarian]

[3] Lewis, D.: Dance technique of Hosé Limon. [José Limón tánctechnikája.] Planétás Kiadó, Budapest, 2000, 3-7. [Hungarian]

[4] Wilson, M., Ryu, J. H., Kwon, Y. H.: Contribution of the pelvis to gesture leg range of motion in a complex ballet movement: grand rond de jambe en l'air en dehors. J. Dance Med. Sci., 2007, 11(4), 118-123

[5] Gamboian, N., Chatfield, S., Woollacott, M. H.: Further effects of somatic training on pelvic tilt and lumbar lordosis alignment during quiet stance and dynamic dance movement. J. Dance Med. Sci., 2000, 4(3), 90-98.

[6] Lee, H. H., Lin, C. W., Wu, H. W., et al.: Changes in biomechanics and muscle activation in injured ballet dancers during a jumpland task with turnout (Sissonne Fermée). J. Sports Sci., 2012, 30(7), 689-697.

[7] Molics, B., Hanzel, A., Nyárády, J., et al.: Utilization indicators of physiotherapy in musculoskeletal and connective tissue disorders for outpatient care. [Fizioterápiás járóbetegellátás igénybevételi mutatói a mozgásszervi kórképek kezelésében.] Magy. Traumatol. Ortop. Kézseb. Plaszt. Seb., 2013, 56(4), 305-315. [Hungarian]

[8] Smith, T. O., Davies, L., de Medici, A., et al.: Prevalence and profile of musculoskeletal injuries in ballet dancers. Physical Therapy in Sport, 2016, 19, 50-56.

[9] Opila, K. A., Wagner, S. S., Schiowitz, S., et al.: Postural alignment in barefoot and high-heeled stance. Spine (Phila. Pa 1976), $1988,13(5), 542-547$.

[10] Kapandji, A. I.: The physiology of the joints. Vol. III. Elservier Science Health Science, Edinburgh, 2007, 211-215.

[11] Somhegyi, A., Lazáry, Á., Feszthammer, A., et al:: Application of special exercises in physical education to develop, automatize and maintain the biomechanically correct posture. [A biomechanikailag helyes testtartás kialakítását, automatizálását és fenntartását szolgáló mozgásanyag beépítése a testnevelésbe.] Népegészségügy, 2014, 92(1), 11-19. [Hungarian]

[12] Járomi, M., Betlehem, J.: Protecting the physical health of healthcare workers... [Az egészségügyi dolgozók fizikai egészségéért...] Nővér, 2005, 18(2), 21-23. [Hungarian]

[13] Ogon, M., Krismer, M., Söllner, W., et al.: Chronic low back pain measurement with visual analogue scales in different settings. Pain, 1996, 64(3), 425-428.

[14] David, K.: Hip and thigh pain: The tensor fascia latae connection. Massage Today, 2012, 12(2), 45-50.

[15] Ángyán, L.: Sport physiology examinations. [Sportélettani vizsgálatok.] Motio Kiadó Bt., Pécs, 1995, 82-83. [Hungarian]

[16] Babalola, J. F., Awolola, O. E., Hamzat, T. K.: Reliability of Kraus-Weber exercise test as an evaluation tool in low back pain susceptibility among apparently healthy university students. Afri- can Journal for Physical Health Education, Recreation and Dance, 2008, 14(2), 188-198.

[17] Oliver, G. D., Dwelly, P. M., Sarantis, N. D., et al.: Muscle activation of different core exercises. J. Strength Cond. Res., 2010, 24(11), 3069-3074.

[18] Smith, J.: Moving beyond the neutral spine: stabilizing the dancer with lumbar extension dysfunction. J. Dance Med, Sci., 2009, 13(3), 73-82.

[19] Cynn, H. S., Oh, J. S., Kwon, O. Y., et al.: Effects of lumbar stabilization using a pressure biofeedback unit on muscle activity and lateral pelvic tilt during hip abduction in sidelying. Arch. Phys. Med. Rehabil., 2006, 87(11), 1454-1458.

[20] Howell, L. A.: Lisa Howell's perfect form core stability course. The Perfect Point Bock, Sydney, 2008, 24-28.

[21] Howell, L. A.: Advanced foot control for dancers. CreateSpace Independent Publ., 2011, 10-13.

[22] Howse, J.: Dance technique and injury prevention. 3rd. ed. Routledge, New York, 2000, 38-42.

[23] Kovácsné, B. V., Járomi, M.: Spinal prevention movement program for dancers. [Gerincprevenciós mozgásprogram táncosoknak.] Magánkiadás, Pécs, 2015. [Hungarian]

[24] Hagins, M.: The use of stabilization exercises and movement reeducation to manage pain and improve function in a dancer with focal degenerative joint disease of the spine. J. Dance Med. Sci., 2011, 15(3), 136-142.

[25] Iunes, D. H., Elias, I. F., Carvalho, L. C., et al.: Postural adjustments in young ballet dancers compared to age matched controls. Phys. Ther. Sport, 2015, 17, 51-57.

[26] Gildea, J. E., Hides, J. A., Hodges, P. W.: Size and symmetry of trunk muscles in ballet dancers with and without low back pain. J. Orthop. Sports Phys. Ther., 2013, 43(8), 525-533.

[27] Swain, C., Redding, E.: Trunk muscle endurance and low back pain in female dance students. J. Dance Med. Sci., 2014, 18(2), 62-66.

[28] Roussel, N., De Kooning, M., Schutt, A., et al.: Motor control and low back pain in dancers. Int. J. Sports Med., 2013, 34(2), 138143.

[29] Mistiaen, W., Roussel, N. A., Vissers, D., et al.: Effects of aerobic endurance, muscle strength, and motor control exercise on physical fitness and musculoskeletal injury rate in preprofessional dancers: an uncontrolled trial. J. Manipulative Physiol. Ther., 2012, 35(5), 381-389.

[30] Corkery, M. B., O'Rourke, B., Viola, S., et al.: An exploratory examination of the association between altered lumbar motor control, joint mobility and low back pain in athletes. Asian J. Sports Med., 2014, 5(4), e24283.

[31] Cumps, E., Verbagen, E., Meeusen, R., et al.: Efficacy of a sports specific balance training programme on the incidence of ankle sprains in basketball. J. Sports Sci. Med., 2007, 6(2), 212-219.

[32] Panjabi, M. M.: The stabilizing system of the spine. Part I. Function, dysfunction, adaptation, and enhancement. J. Spinal Disord., 1995, 5(4), 383-389.

[33] Norris, C.: Back stability. Human Kinetics, Champaign, IL, USA, 2000, 14-42, 43-67, 134-165, 231-246.

[34] Norris, C., Matthews, M.: The role of an integrated back stability program in patients with chronic low back pain. Complement. Ther. Clin. Pract., 2008, 14(4), 255-263.

[35] Rickman, A. M., Ambegaonkar, J. P., Cortes, N.: Core stability: implications for dance injuries. Med. Probl. Perform. Art., 2012, $27(3), 159-64$ 